\title{
Balance Sheet Channel of Monetary Policy: Evidence from Credit Spreads of Russian Firms
}

Filipp Prokopev, University of Michigan ${ }^{1}$

fprokopev@nes.ru

In this paper, I analyse the relationship between the credit spreads of Russian bond issuers and monetary policy shocks. According to the theory of demand-side financial imperfections, in the presence of financial frictions, the higher the net worth of a firm, the lower its external finance premium. The theory of the balance sheet channel of monetary policy suggests that monetary shocks may affect the net worth of a firm through debt outflows. Together, these ideas predict that the external finance premium of more indebted companies is more sensitive to monetary policy shocks. However, my empirical findings from the credit spreads of Russian companies do not support this theory.

\section{Keywords:}

informational asymmetry,

balance sheet channel, monetary

policy shock, external finance

premium, credit spread

JEL Codes: E52, E44
Citation: Prokopev, F. (2021).

Balance Sheet Channel of Monetary

Policy: Evidence from Credit

Spreads of Russian Firms. Russian

Journal of Money and Finance, 80(4), pp. 3-30.

doi: $10.31477 /$ rjmf.202104.03

\section{Introduction}

In recent years, there has been growing interest in studying the linkages between the financial and real sectors of an economy, and such disastrous events as the financial crisis of 2008 and the coronavirus crisis have confirmed the importance of understanding macrofinancial linkages.

Economists have paid a lot of attention to the balance sheet channel of monetary policy. The balance sheet channel rests on the idea that changes in the key rate may affect a firm's financials (both market and book values), thereby influencing its access to external finance due to information asymmetry and

\footnotetext{
1 The author is a graduate of the HSE/NES Programme in Economics (2021) and the winner of the Second Economic Research Competition for Students and PhD Fellows organised by the Bank of Russia and the Russian Journal of Money and Finance.
} 
other financial imperfections. This theory was proposed relatively recently: Bernanke et al. (1999) introduced the notion of the financial accelerator, and Boivin et al. (2010) were among the first scholars to elaborate on the balance sheet channel of monetary policy. It is, therefore, not surprising that empirical papers testing this theory are not numerous.

Usually, researchers of the balance sheet channel look at an economy in the aggregate, like the dynamic stochastic general equilibrium (DSGE) models of Bernanke et al. (1999) and Boivin et al. (2010), or the structural vector autoregressive (SVAR) model of Gertler and Karadi (2015). But important insights may be found via microlevel analysis as well. For example, Ottonello and Winberry (2020) report that investment responds to monetary shocks heterogeneously depending on a firm's leverage and distance from default. They find that more levered companies are less sensitive to monetary shocks. Anderson and Cesa-Bianchi (2020) analyse credit spreads and firm-level balance sheet data and conclude that monetary policy has a more pronounced effect on the credit spreads of more financially constrained firms. Thus, empirical papers in this field often find contradictory results. One way to resolve this controversy is to conduct more empirical research. My paper studies the Russian corporate bond market at the microlevel. The bond market has recently been growing, especially amid the international sanctions that have limited the ability of some companies in the country to access external financing from abroad (Figure 9 in Appendix C, see online version of this paper). The importance of the corporate bond market in the external financing of Russian firms can also be highlighted by the fact that the amounts borrowed are comparable to the amounts of liquidity that firms keep on their balance sheets for current payments (Tables 1-5). To my knowledge, this is the first study of the balance sheet channel within an emerging market economy to use granular credit spread data. It is possible that the lack of data and the illiquidity of the financial markets in emerging economy countries discourage research of this question. However, Russian data on corporate bonds, firms' financials and policy rate forecasts can be used for such a study (with, of course, some caveats, which are articulated in Sections 4, 5, and 6).

Although my paper is close to the approach of Anderson and Cesa-Bianchi (2020), I use a different method for empirical estimation. Those authors use an event-study approach analysing the changes in the dependent variable during short periods which are supposed to absorb monetary policy shocks. Many of the bonds circulating in the Russian corporate bond market are not as liquid as those in the US market, however. Therefore, I use a distributed lag model with twelve lags of the independent variable to allow for a prolonged response to monetary shocks.

The external finance premium (the difference between a firm's costs for raising financing from external and internal sources) is unobservable, which is the main 
obstacle to studies on the topic. There are multiple methods to approximate this premium, with each method reflecting its authors' subjective understanding of the cost of external and internal sources (Brissimis et al., 2018). Nevertheless, De Graeve (2008) demonstrates that credit spreads - a common proxy for the external finance premium - and the measure of the premium calculated based on Bernanke et al. (1999) theoretical model share the similar characteristics: the contemporaneous correlation between these two variables is 0.37 (for a sample period from 1954 to 2004), they decrease substantially after the 1973-1975 recession and they exhibit similar peaks. With that in mind, I use Cbonds data on the whole population of Russian bond issuers to analyse the response of their credit spreads to monetary policy shocks.

Monetary shocks are calculated as the difference between the announced rates and the consensus of the policy rate forecasts of macro analysts. They seem to be rational, meaning that there is no serial correlation in mistakes and no bias. Under the identification assumption that the experts have access to all available information about the current state of the economy and the central bank does not possess exclusive data, these shocks are orthogonal to the macroeconomic environment. In the Russian context, conventional methods of identifying monetary shocks, which include SVAR model estimation or 30-minute shocks on interest rate futures around the interest rate announcement, cannot be applied. This is because of changes in the Bank of Russia policies (which means that the parameters of the SVAR would be time-varying) and the lack of the suitable financial instruments or illiquidity of the latter.

In the next section, I describe the existing literature on this topic. In Section 3, I lay out the theoretical fundament in favour of the hypothesis that the external finance premium of a more indebted firm may respond by a larger increase to a positive monetary policy shock of the same magnitude. The identification assumptions that justify the use of the consensus policy rate forecast to calculate monetary shocks are described in Section 4, together with the dataset. The estimation results (Section 5) suggest that credit spreads do not respond heterogeneously to most lagged monetary shocks, which does not support the existing theory of the balance sheet channel of monetary policy. In Section 6, I provide possible explanations for this result. Section 7 concludes.

\section{Literature review}

In their review of macrofinancial literature, Claessens and Kose (2018) provide a microeconomic justification for financial imperfections, that is, frictions in financial markets that lead to the amplification of real shocks: due to information asymmetries, both lenders and investors have more difficulty estimating the expected rate of return on prospective projects than do a firm's managers or owners. Moreover, lenders and investors do not know whether 
borrowers exert enough effort and choose economically efficient projects, which is a typical moral hazard problem. Therefore, the financial position of a firm may actually affect the availability of external funding since it aligns the incentives of the borrower and the lender, serves as collateral and may indicate the quality of the borrower.

Monetary policy affects a firm's financials by exacerbating financial frictions. Boivin et al. (2010) propose two reasons for this. First, contractionary monetary policy leads to a decline in asset prices (and similarly, expansionary policy results in higher asset prices), which lowers the net worth of firms. Therefore, contractionary monetary policy causes adverse selection and worsens moral hazard problems. These problems, in turn, lead to the financial frictions described in the previous paragraph. Second, monetary policy can affect firms' balance sheets through cash flow: an increase in interest rates causes firms' interest payments to rise, thereby causing their cash flows to decrease.

Empirical evidence in favour of the aforementioned link between monetary shocks and the external finance premium includes the paper of Gertler and Karadi (2015). The authors estimate an SVAR model using high frequency surprises of interest futures as an external instrument. They find that monetary shocks have a large and continuous effect on credit spreads. However, they use the measure of the excess bond premium constructed by Gilchrist and Zakrajšek (2012), which is an aggregate variable cleaned of firm-specific characteristics. Caldara and Herbst (2019) also estimate an SVAR model, but within a Bayesian framework. They construct a proxy for monetary policy shock using high frequency data on federal funds rate futures and incorporate data on its distribution into the model. Similarly to Gertler and Karadi (2015), they report a statistically significant positive response from the aggregate measure of credit spreads to monetary shocks.

While the studies on funding costs, balance sheets and their role in the transmission of monetary policy mentioned in the previous paragraph look at an economy at the aggregate level, some papers do use microlevel data. For example, Ottonello and Winberry (2020) demonstrate that firms with lower default risk and hence, with better financial positions - are more responsive to monetary policy in terms of their investments. However, Cloyne et al. (2018) show that younger firms (which are presumed to be more financially constrained) react to monetary shocks by decreasing their investment by larger amounts. Similarly to Ottonello and Winberry (2020), Priit Jeenas (2019) finds that higher leverage and lower liquid asset holdings at the time of a contractionary monetary shock tend to predict relatively lower fixed capital, inventory, and sales growth in a cross-section of firms. In line with the aggregate-level studies mentioned, Jeenas (2019) shows that the differences between firms develop slowly, four to twelve months after a shock. At the same time, he demonstrates that more financially constrained firms' borrowing costs are more reactive to unexpected changes in 
the policy rate. The author uses the average rate and the total interest expenses paid as a measure of borrowing costs. Anderson and Cesa-Bianchi (2020) are the first to use credit spreads and firm-level balance sheet information. They find that the effect on the credit spreads of more financially constrained firms is relatively more pronounced. The authors use an event-study approach, meaning that they take the difference in credit spreads within a certain window around a monetary shock. ${ }^{2}$ Their paper is the closest to my research, but the approach they use is not applicable in the context of Russia. For an event study, bonds should be traded very often, while many of the bonds traded on the Russian market are quite illiquid, and this is why I choose to estimate a distributed lag model.

\section{Theoretical model}

Here, I describe the two-period partial equilibrium model outlined by Bernanke et al. (1999) and a particular instance of it with specific distribution functions. In addition, I redefine the external finance premium so that it resembles the definition of credit spread. I analyse its properties in the equilibrium of the model to justify the hypotheses tested in the empirical part of this paper.

There are three types of agents: households, entrepreneurs, and retailers. Riskneutral entrepreneurs play a crucial role in the model. They acquire physical capital in each period $t$ for use in period $t+1$ (denoted as $K_{t+1}^{j}$ ). They acquire this physical capital at price $Q_{t}$. The return on capital for firm $j$ is $\omega^{j} R_{t+1}^{k}$, where $\omega$ is an idiosyncratic shock and $R_{t+1}^{k}$ is the ex-post aggregate return on capital. At the end of period $t$ (the beginning of $t+1$ ), entrepreneur $j$ has net worth $N_{t+1}^{j}$. To finance the difference between his expenditures on capital goods and his net worth, he must borrow amount $B_{t+1}=Q_{t} K_{t+1}^{j}-N_{t+1}^{j}$ from a financial intermediary that obtains its funds from households. The intermediary faces opportunity cost equal to the risk-free gross rate of return, $R_{t+1}$. The authors assume a costly state verification problem: if a borrower goes bankrupt, the lender needs to pay share $\mu$ of the firm's value $\omega_{t} R_{t+1}^{k} Q_{t} K_{t+1}^{j}$ in order to figure $\omega_{t}$ out.

If $\omega$ is sufficiently high $(\omega>\hat{\omega})$, the entrepreneur pays out the face value, $\hat{\omega} R_{t+1}^{k} Q_{t} K_{t+1}^{j}$. When the return is low, it goes bankrupt. Taking into account the opportunity cost of lending - the risk-free interest rate $R_{t+1}$ - the authors get the following restriction:

$$
\begin{aligned}
(1-F(\widehat{\omega})) \widehat{\omega} R_{t+1}^{k} Q_{t} K_{t+1}^{j}+(1-\mu) \int_{0}^{\widehat{\omega}} \omega R_{t+1}^{k} Q_{t} K_{t+1}^{j} d F(\omega) & \\
& =R_{t+1} B_{t+1} .
\end{aligned}
$$

The entrepreneur's problem is $\int_{\widehat{\omega}}^{+\infty}(\omega-\widehat{\omega}) R_{t+1}^{k} Q_{t} K_{t+1}^{j} d F(\omega) \rightarrow \max \widehat{\omega}, K$, which is simply the maximisation of the expected profit.

\footnotetext{
${ }^{2}$ In their baseline specification, they consider a one-week change in the spread.
} 
The authors demonstrate that in the setting described above, the optimal capital purchase by an entrepreneur is described by the equation: $Q_{t} K_{t+1}^{j} / N_{t}=\phi\left(s_{t}\right)$, where $\phi(.)^{\prime}>0$ and $s_{t}=E\left\{R_{t+1}^{k}\right\} / R_{t}$ is interpreted as the external finance premium. Thus, they demonstrate that ceteris paribus, a firm's access to external financing depends inversely on its net worth. That is, the higher is a firm's net worth, the more capital it can borrow with a given external finance premium $s_{t}$. On the other hand, the higher is a firm's net worth, the lower is its external finance premium with a given amount of borrowed capital.

However, the authors' definition of external finance premium does not resemble a credit spread. For this reason, I decided to use a different definition of the premium within the somewhat simpler framework with costly state verification outlined by Romer (2011). I describe certain functions from this book and the solution of this model and then analyse the behaviour of the equilibrium external finance premium.

Assume that an entrepreneur has the opportunity to undertake a project that requires one unit of resources, that is, $Q_{t} K_{t+1}^{j}=1$ in the terms of Bernanke et al. (1999). The entrepreneur has wealth $N_{t}$ (henceforth denoted as $N$ ), which is less than one. Thus, he or she must obtain $B_{t+1}=1-N$ units of outside financing to undertake the project. The actual output $y$ (or $\omega_{t} R_{t+1}^{k} Q_{t} K_{t+1}^{j}$ in the terms of Bernanke et al., 1999) is distributed uniformly on $[0,2 \gamma]$. Here, again, assume that the entrepreneur may observe the output without additional cost, while the lender has to pay fixed amount $c<\gamma$.

Under the conditions of this model, the optimal contract is constant. Let $D$ denote the amount proposed in non-default states. The payoff to the lender is equal to $D$ when $y \geq D$ and is equal to $y$ otherwise. So, the lender's return on investments is

$$
R(D)=\frac{2 \gamma-D}{2 \gamma_{P(y \geq D)}} D+{\frac{D}{2 \gamma_{P(y<D)}}}\left(\frac{D}{2}_{E[y \mid y<D]}-c_{\text {verification costs }}\right) .
$$

Under perfect competition and the assumption that both agents are risk free, this return is also equal to $(1+r)(1-N)$, where $r$ is the risk-free interest rate in the economy. It can be shown that the solution of this equation is $D^{*}=2 \gamma-c-\sqrt{(2 \gamma-c)^{2}-4 \gamma(1+r)(1-N)}$.

The borrower's expected payoff is

$$
\gamma-\left(\frac{2 \gamma-D}{2 \gamma} D+\frac{D}{2 \gamma} \frac{D}{2}\right)
$$

When this amount exceeds the opportunity cost of the project - investment in risk-free project $(1+r) N$ - the entrepreneur undertakes it.

Let us analyse the case in which the project is undertaken. The entrepreneur's cost of risky borrowing in this case is 


$$
\begin{aligned}
R_{b}=\left(\frac{2 \gamma-D}{2 \gamma} D+\frac{D}{2 \gamma} \frac{D}{2}\right)_{\begin{array}{l}
\text { expected amount } \\
\text { returned to lender }
\end{array}} /(1-N)_{\text {borrowed amount }} \\
=\frac{D c}{2 \gamma} /(1-N)+(1+r) .
\end{aligned}
$$

Then, the formula that resembles credit spread is

$$
\begin{aligned}
S=R_{b}-1-r=\frac{D c}{2 \gamma} & /(1-N) \\
& =\frac{\left(2 \gamma-c-\sqrt{(2 \gamma-c)^{2}-4 \gamma(1+r)(1-N)}\right) c}{2 \gamma(1-N)} .
\end{aligned}
$$

In the Appendix A, I show that $S_{N}^{\prime}<0$. That is, the higher is an entrepreneur's worth, the lower is his external finance premium.

Since the external finance premium is unobservable, several different definitions exist. I have demonstrated above that, for the external finance premium defined both in Bernanke's way, that is, as the ratio of the cost of internal financing $E\left[R_{k}\right]$ to the cost of external financing $R$, and as the credit spread, the same result holds: under costly state verification, the external finance premium is inversely proportional to net worth.

Now let us introduce the balance sheet channel of monetary policy to this setting. It is articulated verbally by Boivin et al. (2010), but I will use a simple mathematical example to illustrate the logic. Imagine that there are two firms that differ only in their leverage $l$ (they have similar equity, mark-to-market assets and liquid assets). Then, suppose that the amount of risky debt on the balance sheet of the first firm $D_{1}$ exceeds that on the balance sheet of the second firm $D_{2}$, that is, $l_{1}>l_{2}$. Then for the same monetary shock $\Delta r, \Delta N_{1}=D_{1} \times \Delta r>D_{2} \Delta r$ (which is equal to $\Delta N_{2}$ ). That is, for the same shock, the net worth of the more levered company should react more.

To get a complete picture, take the derivative of credit spread with respect to $r$ : it can be seen that

$$
\begin{aligned}
& S_{r}^{\prime}=S_{N}^{\prime} N_{r}^{\prime}-1 / 2 \times 1 / \\
& \times(-4 \gamma(1-N)) /(1-N) \times c / 2 \gamma \\
& \quad=S_{N}^{\prime} N_{r}^{\prime}+c / \sqrt{(2 \gamma-c)^{2}-4 \gamma(1+r)(1-N)} .
\end{aligned}
$$

The first term of this equation is positive, because both $S_{N}^{\prime}<0$ and $N_{r}^{\prime}<0$. Moreover, the higher leverage $l$ is, the more negative $N_{r}^{\prime}$, and so the more pronounced the response of the credit spread is. The last term is also clearly positive.

So, in this model, due to costly state verification and the balance sheet channel, there is a heterogeneous response to changes in the policy rate. To be 
more precise, more levered firms are more sensitive to monetary policy, while the overall relationship between the policy rate and credit spread is positive. That is, in the regression of credit spreads on the interaction of leverage and monetary shocks (Models (1) and (2) in Section 5), the coefficient of interest is expected to be positive.

\section{Data}

\subsection{Monetary shocks}

The reason it is not valid to regress credit spreads directly on interest rates is rather straightforward: monetary policy is endogenous to the current macroeconomic situation. Indeed, on the one hand, a central bank reacts to current conditions and, on the other hand, aims to affect them. Thus, in macroeconomic literature related to monetary policy, authors often construct exogenous monetary shocks and analyse them rather than policy rates.

Usually, SVAR models are used for these purposes (examples include Gertler and Karadi, 2015; Caldara and Herbst, 2016; Cloyne et al., 2018). Once an SVAR model is estimated, it is possible to identify structural monetary policy shocks. These models are estimated on a quarterly frequency, like most macroeconomic measures (GDP or inflation), and impose stability restrictions on the relationships between the variables in the model. In the context of Russia, these features both prevent us from estimating this type of model appropriately. First, the interest rate has been used as a policy instrument in Russia only since 2013, which leave researchers with a short sample period. More than that, there was a period of transition from exchange rate targeting to inflation targeting in the period from 2010 to 2015, which violates the assumption of stable coefficients in the model. The latter issue can be resolved with the TVP-VAR (Time-Varying Parameter Vector Autoregressions) approach developed by Primiceri (2005). This model was estimated on Russian data by Borzykh (2016) to analyse the bank lending channel in Russia.

Another approach for the identification of monetary shocks uses highfrequency data on interest rate futures. According to the identification assumption, percentage changes in futures prices in the 30-minute window around a policy rate announcement reflect only the change in market expectations of the policy rate: a futures contract's riskiness hardly changes in this short period for any other reason. Ottonello and Winberry (2020) use this approach. Unfortunately, there are no such instruments on the Russian market. The most similar financial products are futures on RUONIA and MosPrime - indicative rates - but they are traded very rarely, only several times per month, while for identification, the contracts must be traded almost every minute, at least around a policy rate announcement. 
However, there are some instruments that are traded at the needed frequency, namely foreign exchange swaps. With these contracts, some authors calculate implied policy rates under the assumption that covered interest rate parity (CIP) holds. For example, Tishin (2019) writes down USD-RUB CIP as follows:

$$
\frac{F_{t}\left[S_{(t+T)}\right]-S_{t}}{S_{t}} \frac{365}{T}=i_{t}^{R U B}-i_{t}^{U S D},
$$

where $S_{t}$ is spot exchange rate, $T$ is time to bond maturity, $F_{t}()$ is futures rate determined at time $t$ for a maturity-moment spot exchange rate. Using the 30-minute time window $(\tau-10 ; \tau+20)$ around policy decision moment $\tau$, changes in the implied policy rate can be constructed as follows:

$$
\begin{aligned}
& \frac{F_{t, \tau-10}\left[S_{t+T}\right]-S_{t, \tau-10}}{S_{t, \tau-10}} \frac{365}{T}=i_{t, \tau-10}^{R U B}-i_{t, \tau-10}^{U S D}, \\
& \frac{F_{t, \tau+20}\left[S_{t+T}\right]-S_{t, \tau+20}}{S_{t, \tau+20}} \frac{365}{T}=i_{t, \tau+20}^{R U B}-i_{t, \tau+20}^{U S D} .
\end{aligned}
$$

Assuming $i_{t}^{U S D}$ does not change in this period,

$$
\begin{aligned}
& i_{t, \tau+20}^{R U B}-i_{t, \tau-10}^{R U B} \\
& \quad=\left(\frac{F_{t, \tau+20}\left[S_{t+T}\right]-S_{t, \tau+20}}{S_{t, \tau+20}}-\frac{F_{t, \tau-10}\left[S_{t+T}\right]-S_{t, \tau-10}}{S_{t, \tau-10}}\right) \frac{365}{T} .
\end{aligned}
$$

It must also be assumed that within this 30-minute time span, no other shocks to futures rates $F_{t}\left[S_{t+T}\right]$ occur and the rate responds only to the announcement. Therefore, this change in the implied rate reflects the part of the monetary policy decision that was not predicted and explained by market agents based on macroeconomic variables. This form of CIP usage is quite restrictive and not particularly convincing though, given that multiple authors document significant deviations from CIP (for instance, Du et al., 2018).

Based on my analysis of the trading data available on Finam, foreign exchange swaps with maturity of more than one day are not liquid enough to use in the method described in the previous paragraph. On the other hand, though swaps with one-day maturity are very liquid, the assumption of unchanging risk within the 30-minute window is not likely to hold. Nevertheless, I use shocks calculated via the method above based on swaps with one-day maturity as an alternative definition of monetary surprises to check the robustness of the results (see Table 11 in Appendix B). The main conclusion does not change: similarly to the estimates from the baseline specification, there is no statistically significant heterogenous reaction to monetary shock. 
I calculate monetary shock (see Figure 1) as the difference between the policy rate actually announced and the consensus forecast of it. Before each planned key rate meeting of the Bank of Russia Board of Directors, a number of analysts from major financial firms are surveyed by Bloomberg. It is assumed that the average forecast reflects market expectations of the rate that should be set by the central bank based on current macroeconomic conditions. Thus, the difference between the actual rate announced and the consensus forecast is a monetary shock orthogonal to all other shocks in the real economy and the financial sector, and, therefore, it can be thought of as a noisy proxy for an exogenous monetary policy shock. Potentially, this discrepancy may be driven by new information that arrives in the period between the announcement and the publication of the forecast or by exclusive information available only to the regulator. However, the analysts are surveyed several days prior to the announcement, and it seems sensible to believe that the most qualified analysts can scrutinise the markets as well as the regulator's staff does. These are the identification assumptions that cannot be tested, but I believe in their validity and present some suggestive evidence.

Figure 1. Monetary shocks (in basis points)

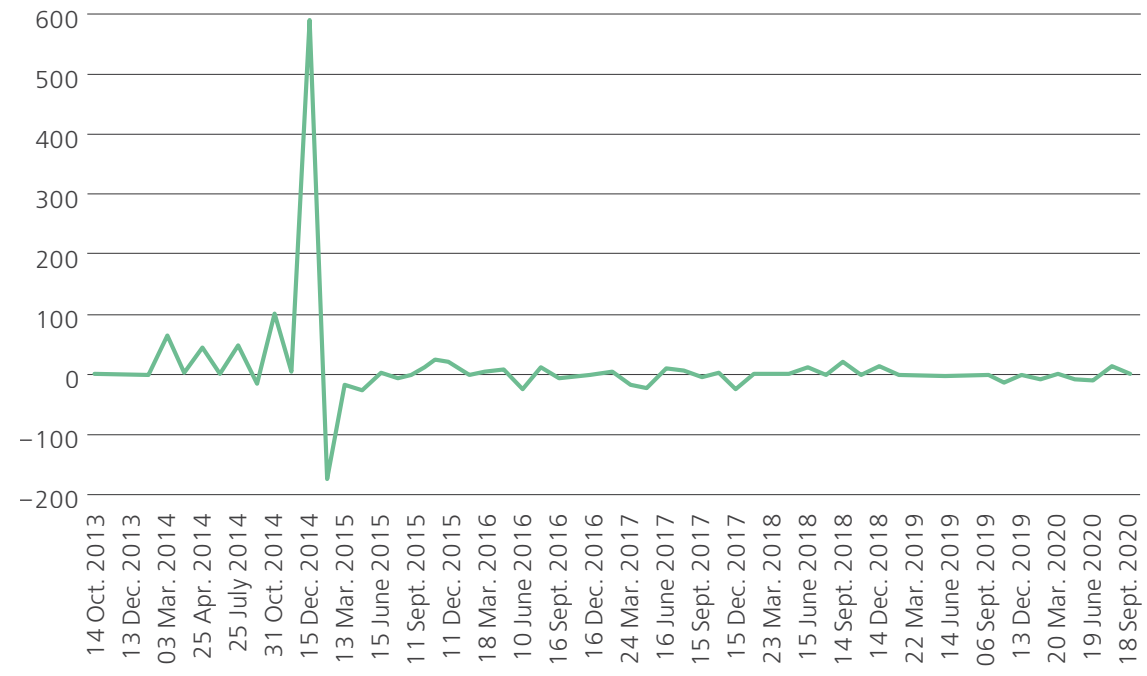

Note: Monetary shocks calculated as the difference between the consensus policy rate forecast (Bloomberg surveys) and the actual rate announced by the regulator at a particular date.

Source: Bloomberg, Bank of Russia, author's calculations

It can be seen from the Figure 1 that consensus policy rate forecasts are likely to be rational. First, on average, the deviation is close to zero: sometimes, analysts overestimate the key rate and in other periods, they underestimate it, but the frequencies of under- and overestimation are quite similar. The t-test 
supports this intuition: the p-value of the t-test with the null hypothesis of the mean being equal to zero is 0.31 , which means that the hypothesis that the mean is different from zero cannot be rejected. Second, it seems that there is no autocorrelation in the mistakes: periods with a positive discrepancy, for example, are followed by periods of underestimation of the key rate as often as periods of overestimation. The Durbin-Watson statistic for the series of shocks is equal to 2.5 , so the test supports the intuition, since the statistic lies at the right edge of the interval from 1.5 to 2.5 , which is used as a rule of thumb for the rejection of serial correlation.

Two meetings were not planned. One was caused by the urgent need to resolve the currency crisis of December 2014. The other one was in March 2014. Thus, policy rate forecasts were unavailable at these dates. I use the yield to maturity of the most liquid Russian government bonds maturing right after the announcements as a proxy for market expectations of the interest rate to fill these two gaps.

\subsection{Financials and credit spreads}

I have collected data on the credit spreads and other characteristics of the bonds from Cbonds. This database provides information on the whole population of Russian bond issuers (at least for bonds denominated in roubles), which is particularly important to my research. For my analysis, I have used firms' book characteristics from IFRS filings (when unavailable, I have resorted to the reports filled in accordance with the national accounting standards) collected from Cbonds, SPARK, and Interfax. Before filtering, the total number of year-bond observations is around 46,000.

Credit spreads have some advantages over other popular proxies for the external finance premium. First, credit spreads are available at a daily frequency, which makes them a source of relevant information about the current cost of debt. Moreover, compared to borrowing costs measured by interest payments, as reported in a firm's balance sheet (Ottonello and Winberry, 2020), or with data on bank loans, credit spreads are constructed based on market prices that reflect the competent view of all market participants regarding the borrower's financial state and, thus, the riskiness of the debt. Even though some bonds are not traded very often and quotations for them are, thus, less informative, the majority of bonds are liquid enough to allow the information to be incorporated into the prices.

Special purpose vehicles (SPV), that is, entities that are established specifically to attract external financing for their parent companies (for example, 'QIWI Finance' was the SPV of 'QIWI'), constituted 42 out of 623 firms. For them, I use financial metrics of their parents.

The sample period is from September 2013 to the end of 2020. The main reason behind this choice is the relatively stable policy of inflation targeting. In a nutshell, in 2013 the Bank of Russia started to use the key rate as its main policy tool. 
The sample was constructed in the following way: at any point in time, only bonds that were floating in the market when all twelve previous monetary shocks realised were included. Some bonds matured earlier and were not included in the sample. The selection in the sample, that is, the presence of particular bonds in the market is arguably not correlated with monetary shocks: even if the shocks affect credit spreads, their influence is hardly so large that it deters companies from borrowing in the corporate bond market. Moreover, companies are not able to predict future monetary shocks at the moment when they decide to enter the bond market, and, thus, this aspect of selection into the sample is not correlated with monetary shocks.

Table 1. Summary statistics, bonds without oferta

\begin{tabular}{lllllll} 
& Mean & St. dev. & $\begin{array}{l}\text { 5th } \\
\text { percentile }\end{array}$ & Median & $\begin{array}{l}\text { 95th } \\
\text { percentile }\end{array}$ & $\begin{array}{l}\text { Number of } \\
\text { observations }\end{array}$ \\
\hline Spread & 357.475 & $4,011.758$ & -610.722 & 129.095 & 933.958 & 19,723 \\
\hline $\begin{array}{l}\text { Leverage } \\
\text { (total assets over net worth) }\end{array}$ & 693.334 & $11,083.142$ & 0.354 & 5.090 & 768.747 & 2,387 \\
\hline $\begin{array}{l}\text { Leverage } \\
\text { (debt over total assets) }\end{array}$ & 0.745 & 0.239 & 0.262 & 0.836 & 0.999 & 2,387 \\
\hline Net worth & 67.510 & 260.773 & 0.004 & 6.024 & 283.175 & 2,403 \\
\hline Total assets & 215.111 & 844.752 & 0.344 & 30.143 & 844.949 & 2,388 \\
\hline Cash & 8.703 & 28.495 & 0.000 & 0.183 & 41.089 & 2,153 \\
\hline Maturity & $1,616.623$ & $1,122.683$ & 546.000 & $1,099.500$ & $3,640.000$ & 884 \\
\hline Coupon & 0.086 & 0.040 & 0.000 & 0.089 & 0.145 & 882 \\
\hline Duration & 576.730 & 655.667 & 13.000 & 437.325 & $1,584.910$ & 884 \\
\hline Amount outstanding & 7.108 & 10.664 & 0.250 & 5.000 & 20.000 & 884 \\
\hline
\end{tabular}

Note: The sources of data are Cbonds and Rusbonds (bond data) and SPARK and Interfax (issuers' financials). Spread is measured in basis points. Maturity and duration are measured in days. On Cbonds, only G-spread is calculated: the difference between a bond's yield and the corresponding point on the G-curve, that is the yield curve of a synthetic zero-coupon government bond with a corresponding duration. Net worth (equity), total assets, cash, and amount outstanding are measured in billions of roubles; these are book values, since a significant part of the sample consists of private firms. Summary statistics for firm characteristics are calculated based on quarterly data, and, therefore, the number of observations is smaller. Statistics for bond characteristics other than credit spread are calculated based on the first point for each firm within the sample (first occurrence).

Source: compiled by the author

Moreover, most of the defaulting companies default at maturity, when they have to pay the face value of bonds, and are, thus, still included in the sample, so there is also no sorting out based on the fact of default. However, some firms violated covenants before maturity, or to be more precise, were not able to pay their coupons. Thus, if their default is caused by the effects of monetary policy, their falling out of the sample may cause sample selection bias. In contrast to the bonds selected in the sample, the external finance premium of bonds on which there was a technical default is likely to be more responsive to monetary shock. Contractionary policy, perhaps, affects the balance sheets of defaulting companies to a larger extent, meaning that their net worth decreases considerably. Thus, I may have included 
firms that are less vulnerable to monetary policy in the final sample. The fact that I fail to find significant responses may be explained by this negative selection bias, which distorts the estimated coefficients towards zero. This concern is critical when many firms are sorted out of the sample due to technical defaults, but in my case, only 14 firms were excluded from the final sample for this reason, so it is unlikely that they led to any bias.

Around 55\% of the total number of year-bond observations constitute bonds with oferta (Table 2). Oferta gives investors the opportunity to sell a bond at specific oferta dates, and these bonds may, therefore, react to monetary shocks differently, since the value of the embedded put option is also influenced by the Bank of Russia decisions regarding the key rate. Thus, they should be either excluded from the sample or allowed to have different coefficients. Anderson and Cesa-Bianchi (2020) use option-adjusted spreads cleaned of the value of the embedded option. However, due to a lack of data, such adjustments cannot be made for the bonds in my sample. Compared to American callable bonds, Russian bonds with oferta have the important feature of a floating coupon rate. The opportunity to adjust the coupon rate after an oferta date allows the issuer to determine the current price of a bond. It may deter investors from realising their put options by setting its coupon rate a little bit higher and, thereby, increasing the current price of the bond, and when it is optimal for the issuer to redeem a bond early, it can decrease the coupon rate, incentivising investors to exercise their put options. Thus, these bonds with oferta have both embedded put and call options, which effectively makes them a combination of different short-term bonds (each of them maturing at an oferta date). In my baseline specifications, I focus only on bonds without oferta, but I also re-estimate the same models on the larger sample of bonds including those with oferta. For this robustness check, I treat bonds with oferta as several sequential bonds. The results are robust to the augmentation of the sample (see Table 10 in Appendix B).

In Tables 1 and 2, two definitions of leverage are presented. The first - total assets over net worth - is the same as Bernanke et al. (1999) use. The second is that used by Anderson and Cesa-Bianchi (2020): debt over total assets. The tables summarise information on ruble bonds floating on the Moscow Exchange from September 2013 to December 2020. The characteristics of the issuers, such as leverage, net worth, total assets, and cash, are also summarised here.

Bonds with oferta have a higher mean credit spread. Their issuers have lower leverage and higher net worth on average, and they have longer times to maturity, but shorter durations, which basically means that the options are often exercised. Despite these differences in mean values, the two groups of bonds and issuers are statistically indistinguishable, meaning that the confidence intervals for the means of one group include the mean values of the other group.

Time points at which balance sheet data were not available were also excluded (I did not use statistical methods, such as extrapolation, to fill the gaps because that 
may have introduced unnecessary noise to the data). Around 5\% of observations were filtered out. The exclusion of these points arguably does not lead to any selection bias, since the availability of financial data is arguably not related to the effect of monetary shocks.

Table 2. Summary statistics, bonds with oferta

\begin{tabular}{llllllll} 
& Mean & St. dev. & $\begin{array}{l}\text { 5th } \\
\text { percentile }\end{array}$ & Median & $\begin{array}{l}\text { 95th } \\
\text { percentile }\end{array}$ & $\begin{array}{l}\text { Number of } \\
\text { observations }\end{array}$ \\
\hline Spread & 443.643 & $2,891.583$ & -216.993 & 152.315 & 914.719 & 26,407 \\
\hline $\begin{array}{l}\text { Leverage } \\
\text { total assets over net worth) }\end{array}$ & 198.047 & $1,516.845$ & 0.386 & 5.656 & 501.992 & 2,662 \\
\hline $\begin{array}{l}\text { Leverage } \\
\text { (debt over total assets) }\end{array}$ & 0.766 & 0.226 & 0.279 & 0.850 & 0.998 & 2,662 \\
\hline Net worth & 140.475 & 690.045 & 0.009 & 10.777 & 541.343 & 2,664 \\
\hline Total assets & 354.580 & $1,264.546$ & 0.428 & 64.735 & $1,214.291$ & 2,666 \\
\hline Cash & 16.911 & 53.882 & 0.000 & 0.773 & 77.274 & 2,361 \\
\hline Maturity & $2,808.971$ & $1,808.602$ & 966.000 & $2,548.000$ & $5,460.000$ & 815 \\
\hline Coupon & 0.082 & 0.038 & 0.001 & 0.083 & 0.145 & 632 \\
\hline Duration & 408.939 & 398.003 & 24.000 & 274.265 & $1,232.400$ & 822 \\
\hline Amount outstanding & 7.415 & 9.510 & 0.500 & 5.000 & 20.000 & 822 \\
\hline
\end{tabular}

Note: See note under Table 1.

Source: compiled by the author

Table 3. Summary statistics, financial firms

\begin{tabular}{lllllll} 
& Mean & St. dev. & $\begin{array}{l}\text { 5th } \\
\text { percentile }\end{array}$ & Median & $\begin{array}{l}\text { 95th } \\
\text { percentile }\end{array}$ & $\begin{array}{l}\text { Number of } \\
\text { observations }\end{array}$ \\
\hline Spread & 364.576 & $2,515.123$ & -522.638 & 162.126 & $1,000.598$ & 24,247 \\
\hline $\begin{array}{l}\text { Leverage } \\
\text { (total assets over net worth) }\end{array}$ & 656.745 & $10,946.054$ & 1.035 & 7.916 & $1,222.552$ & 2,376 \\
\hline $\begin{array}{l}\text { Leverage } \\
\text { (debt over total assets) }\end{array}$ & 0.859 & 0.133 & 0.509 & 0.888 & 0.999 & 2,376 \\
\hline Net worth & 18.513 & 51.641 & 0.002 & 3.603 & 94.713 & 2,392 \\
\hline Total assets & 156.639 & 395.722 & 0.224 & 31.543 & 558.709 & 2,380 \\
\hline Cash & 11.551 & 39.389 & 0.000 & 0.223 & 44.506 & 1,955 \\
\hline Maturity & $2,562.476$ & $1,545.962$ & $1,092.000$ & $1,827.000$ & $5,460.000$ & 921 \\
\hline Coupon & 0.078 & 0.041 & 0.000 & 0.083 & 0.140 & 921 \\
\hline Duration & 445.374 & 546.911 & 29.000 & 294.000 & $1,336.520$ & 921 \\
\hline Amount outstanding & 6.366 & 6.024 & 1.000 & 5.000 & 15.00 & 921
\end{tabular}

Note: See note under Table 1.

Source: compiled by the author

In the extant literature, it is argued that the balance sheet channel works mostly through non-financial firms, since financial companies, like banks, have multiple sources of external financing other than debt: interbank loans or certificates of deposit, for example. Other reasons include different attitudes towards risk and distinct business models. Therefore, I estimate the model only on the subsample of non-financial firms (approximately half of the initial sample (Table 4)). 
Descriptive statistics can be found in the Table 5. Again, the statistics for the two subsamples are not significantly different, that is, their confidence intervals overlap. In the final sample, only bonds of non-financial firms without oferta are left (Table 5).

Table 4. Summary statistics, non-financial firms

\begin{tabular}{lllllll|l} 
& Mean & St. dev. & $\begin{array}{l}\text { 5th } \\
\text { percentile }\end{array}$ & Median & $\begin{array}{l}\text { 95th } \\
\text { percentile }\end{array}$ & $\begin{array}{l}\text { Number of } \\
\text { observations }\end{array}$ \\
\hline Spread & 453.045 & $4,203.382$ & -263.305 & 122.258 & 840.790 & 21,883 \\
\hline $\begin{array}{l}\text { Leverage } \\
\text { (total assets over net worth) }\end{array}$ & 232.609 & $2,347.798$ & 0.268 & 2.505 & 404.112 & 2,673 \\
\hline $\begin{array}{l}\text { Leverage } \\
\text { (debt over total assets) }\end{array}$ & 0.664 & 0.261 & 0.211 & 0.715 & 0.998 & 2,673 \\
\hline Net worth & 183.988 & 722.834 & 0.017 & 16.739 & 697.532 & 2,675 \\
\hline Total assets & 406.206 & $1,439.443$ & 1.207 & 62.930 & $1,248.254$ & 2,674 \\
\hline Cash & 14.100 & 46.939 & 0.000 & 0.581 & 69.801 & 2,559 \\
\hline Maturity & $2,367.278$ & $1,659.603$ & 728.000 & $1,820.000$ & $4,368.000$ & 785 \\
\hline Coupon & 0.091 & 0.032 & 0.005 & 0.088 & 0.145 & 675 \\
\hline Duration & 573.810 & 478.911 & 25.000 & 491.430 & $1,491.800$ & 785 \\
\hline Amount outstanding & 8.625 & 12.737 & 0.250 & 5.000 & 20.000 & 785 \\
\hline
\end{tabular}

Note: See note under Table 1.

Source: compiled by the author

Table 5. Summary statistics, final sample

\begin{tabular}{lllllll} 
& Mean & St. dev. & $\begin{array}{l}\text { 5th } \\
\text { percentile }\end{array}$ & Median & $\begin{array}{l}\text { 95th } \\
\text { percentile }\end{array}$ & $\begin{array}{l}\text { Number of } \\
\text { observations }\end{array}$ \\
\hline Spread & 408.851 & $5,271.394$ & -413.073 & 123.474 & 864.916 & 8,624 \\
\hline $\begin{array}{l}\text { Leverage } \\
\text { total assets over net worth) }\end{array}$ & 292.573 & $2,515.098$ & 0.306 & 2.058 & 430.840 & 1,652 \\
\hline $\begin{array}{l}\text { Leverage } \\
\text { (debt over total assets) }\end{array}$ & 0.646 & 0.253 & 0.234 & 0.673 & 0.998 & 1,652 \\
\hline Net worth & 182.139 & 579.884 & 0.014 & 18.073 & 650.932 & 1,653 \\
\hline Total assets & 398.401 & $1,301.420$ & 1.254 & 63.053 & $1,255.562$ & 1,661 \\
\hline Cash & 11.415 & 31.137 & 0.000 & 0.664 & 55.654 & 1,564 \\
\hline Maturity & $2,004.050$ & $1,363.395$ & 728.000 & $1,820.000$ & $3,640.000$ & 464 \\
\hline Coupon rate & 0.092 & 0.033 & 0.001 & 0.090 & 0.145 & 464 \\
\hline Duration & 648.080 & 581.113 & 26.000 & 507.435 & $1,793.170$ & 464 \\
\hline Amount outstanding & 8.659 & 13.46 & 0.20 & 5 & 25.00 & 464
\end{tabular}

Note: See note under Table 1.

Source: compiled by the author

It is important to notice that non-financial firms are quite different within the final sample: the spreads vary considerably (the standard deviation is 5,271 basis points, or $52.7 \%$ ), as does the leverage (the standard deviation is 2,515 ).

Figure 2 demonstrates that there is variation in spreads in both the crosssectional and time dimensions. In the period from 2014 to 2016, the distribution of the spreads is much wider than in the following years. More than that, the mean values of the spreads are higher during that period, fluctuating within the interval 
from 1,000 to 2,000 , while in the subsequent years, credit spreads mostly stay around 100 basis points. The external premium depends on macroeconomic conditions. Thus, the high spreads and their cross-sectional variation around December 2014 may be attributed to Russian financial crisis. In particular, they could have been caused by the well-known rouble crash: firms that suffered more from the devaluation faced a larger external finance premium, while strong companies enjoyed the discount. To capture macroeconomic shocks (like the one described above) that affect the distribution of credit spreads, I add timefixed effects to the empirical model. In order to allow for time-invariant crosssectional differences, I include firm-fixed effects.

Figure 2. Credit spread

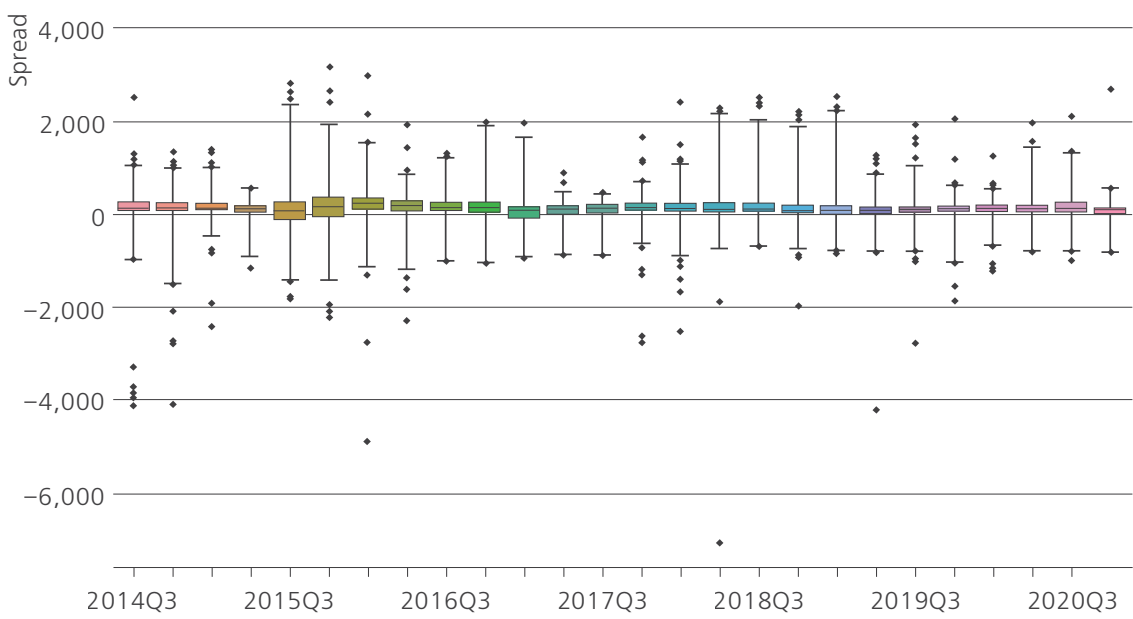

Note: This graph summarises information on the credit spreads of non-callable bonds of non-financial firms. The source of the data is Cbonds. On Cbonds, spread is calculated as the difference between a firm's yield, derived from quotations, and a corresponding point on the G-curve. Each bar represents a different quarter, and the bars plot the 95-percent distribution of credit spreads in a given quarter. The whiskers show the next $4 \%$, and the rest are individual outliers. As we can see, there is heterogeneity in credit spreads on both the cross-sectional and time directions.

Source: Cbonds, author's calculations

The large number of bonds with negative spreads is itself an important observation. This means that these bonds are traded at a premium, and one should expect that only a few outlying companies could enjoy such favourable trade conditions. However, more than a half of the final sample had a negative spread at some points in time, and not all such companies look like particularly trustworthy borrowers. Thus, it is most likely that the negative spreads can be explained by the significant riskiness of Russian government bonds. Since they are traded with a large risk premium, many corporate bonds look relatively risk free.

In the final sample, some companies have several bonds traded on the exchange simultaneously. The distribution is presented in Figure 8 
(Appendix C). We can see that most firms in my sample have a few bonds. Next, I calculate the weighted average of all spreads that remain in the sample for a given company. The spreads are weighted according to the value of the company's outstanding bonds (those which are included in the sample). These weights sum to one and reflect the relative importance of each bond in the external financing of the firm.

Another important characteristic of the final sample is that approximately half of the sample consists of firms that do not have floating stock. My final sample includes 120 issuers, of which 36 firms are limited liability companies, 35 firms are non-public joint stock companies, and the rest of the sample is composed of public joint stock companies. This is why balance sheet data are used for the estimation. Of course, market values are believed to effectively reflect all available information regarding the corresponding metrics of a firm, but given the characteristics of the sample, the use of market values is infeasible.

Figure 3. Leverage (debt over total assets)

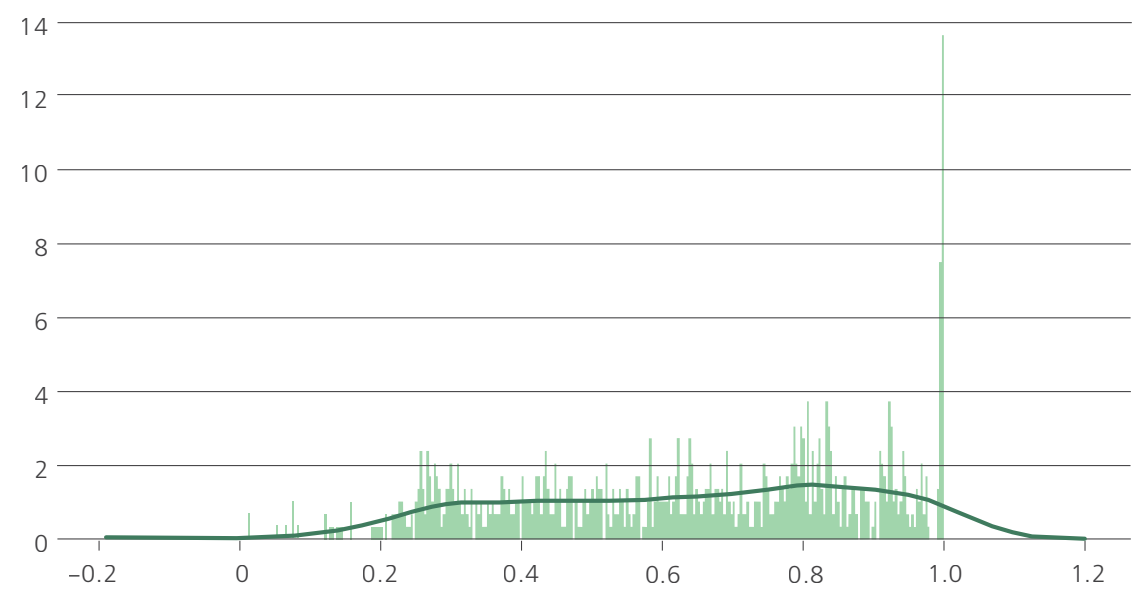

Note: This graph plots the distribution of leverage (debt over total assets) in the final sample of 120 firms. The spike can be attributed to SPV firms. Once their financials are replaced with those of their parent' companies, the distribution becomes more symmetric.

Source: author's calculations

As can be seen from Table 5, leverage, as defined by Bernanke's method, is skewed to the right: the standard deviation is high while the 95th percentile is close to the mean. Indeed, analysis of the data demonstrates that the top $5 \%$ of values for leverage are very high (up to 45,000). Since ordinary least square method (OLS) is sensitive to outliers, this may be an argument in favour of the second definition. However, I present the results of estimation with both these variables. The values for leverage defined by the second method are bounded between zero and one, and they seem to be distributed more or less symmetrically. 


\section{Empirical models}

\subsection{Distributed lag model}

Given that individual bonds may be quite illiquid, their prices and, thus, spreads may incorporate a monetary shock for a long time. Moreover, in the existing literature, there is some evidence for a prolonged response from the whole corporate bond market - which is obviously more liquid than the markets for individual bonds - to monetary shocks (for example, Gertler and Karadi, 2015). I, therefore, estimate the following model with monthly frequency and the interaction of the twelve lags (from zero to eleven) of monetary shock with the 12th lag of leverage as the regressors of interest:

$$
\begin{aligned}
\text { WeightedSpread }_{i t}= & \beta_{0}+\sum_{p=0}^{11} \beta_{p} \times \text { leverage }_{i t-12} \\
& \times \text { MonetaryShock }_{t-p}+X_{i t}+\alpha_{t}+\gamma_{i}+\epsilon_{i t},
\end{aligned}
$$

where $\alpha_{t}$ and $\gamma_{i}$ are time and firm fixed effects and $X_{i t}$ is the set of controls.

In every specification, the dependant variable is the average spread of a given firm $i$ within a given month $t$. To calculate it, the spreads of every bond of the given firm included in the final sample are summed with weights proportional to their amounts outstanding. Therefore, this average spread aggregates all the information about the market's view of the financial health of the firm. At the same time, I make sure that the regressors and the regressand are all at the timefirm level.

Leverage is calculated as debt divided by total assets. There are many alternative definitions of leverage, including the ratio of total assets to net worth. In the Appendix B, I show that the main conclusion does not change with this alternative definition. Leverage is calculated using balance sheet variables because approximately half of the firms in the sample do not have floating stock. Although the variable is measured at quarterly frequency, its interaction with monetary shocks results in monthly fluctuations. An alternative way to solve this problem of quarterly frequency is the interpolation of quarterly values, but this may result in unnecessary noise in the data.

Time fixed effects capture the influence of factors within a given month that affect the credit spreads of all firms in the same way, such as macroeconomic shocks. This is why I do not include monetary shocks themselves within the model. Firm fixed effects are included in the model as well. The estimation of fixed effects proceeds with the use of dummies for each unit $i$ and each month $t$. The model also includes the 12th lag of such firm characteristics as amount of cash, net worth, size, and leverage to avoid potential omitted variable bias due to the correlation of these characteristics with the 12th lag of leverage. 
Table 6. Baseline models

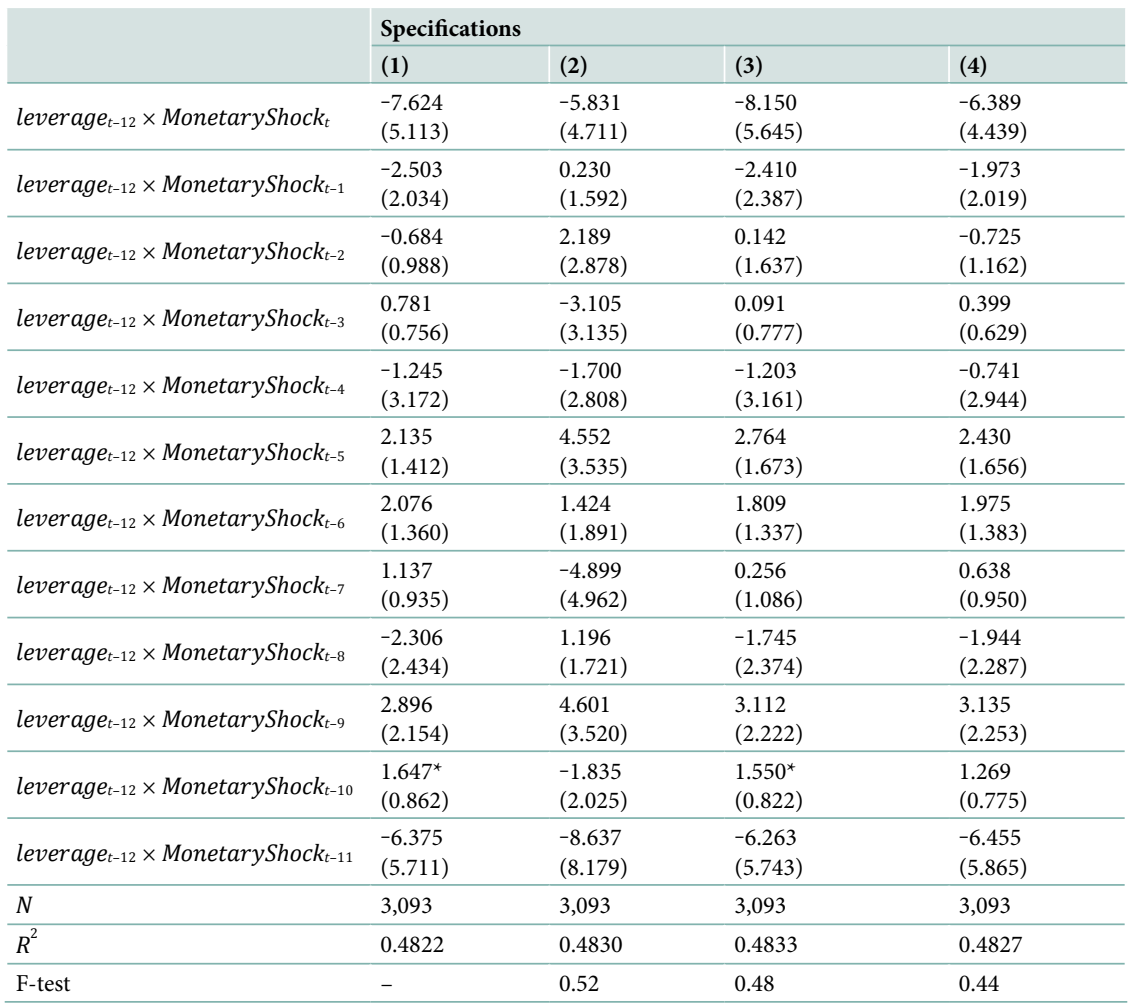

Note: Standard errors in parentheses; ${ }^{* *} p<0.01,{ }^{* *} p<0.05,{ }^{*} p<0.1$. The models are estimated with time- and firm-fixed effects, which is done by directly including dummies (75 time dummies and firm dummies) and the 12th lags of cash, net worth, leverage, and size as control variables. Standard errors are clustered at the firm level. I report only estimates for the regressors of interest because control variables are not the subject of this research, and most are statistically insignificant. In specification (1), only the regressors described above are included. Specification (2) includes additionally interaction terms between the different lags of monetary shocks and the 12 th lag of size (log of total assets). In the other specifications, interactions with lagged net worth and cash are also included.

Source: author's calculations

I identify a monetary shock as a difference between the actual rate and the consensus forecast for it derived from Bloomberg's surveys. It is worth mentioning, though, that these shocks are calculated for each month, including those in which the regulator did not announce any decisions. In such months, ${ }^{3}$ the value for monetary shock is simply zero. The identification assumption that these shocks are exogenous cannot be tested explicitly, however, I present suggestive evidence in favour of this assumption. If these shocks are orthogonal to all other factors determining credit spreads, then the inclusion of additional controls should not change the estimates considerably. It can be seen that after

\footnotetext{
3 The Bank of Russia makes, on average, eight announcements regarding the policy rate per year, so there are four months per year in which no decision is made.
} 
the set of additional controls (the twelfth lags of net worth, leverage, size, and cash) are excluded from specifications (1) - (4) (see Table 6), the estimated coefficients remain almost unaffected (see Table 7 in Appendix B), and the main conclusion does not change: no statistically significant heterogeneity in reaction to monetary shocks is found.

Similarly to Ottonello and Winberry (2020), I include the interactions of other firm characteristics with shocks as control variables and show that the results of the estimation do not change. As controls, I use the interactions of the 12th lags of size (logarithm of total assets) in specification (2), net worth (specification (3)), and cash (specification (4)) with lags of monetary shocks. These interaction terms are omitted variables only if there is an additional direction of heterogeneity along these variables. Otherwise, the interaction of the endogenous leverage with exogenous monetary shocks is arguably exogenous. ${ }^{4}$

The estimates are presented in Table 6. The first model includes only terms for interaction with leverage, while the second also includes interactions with size, the third - with net worth, and the fourth - with cash. Clearly, the results of the estimation do not change when these controls are included, which suggests that the baseline specification (1) is not affected by omitted variable bias. Moreover, the results of the corresponding F-tests suggest that the hypotheses that the controls are jointly insignificant cannot be rejected.

To understand the interpretation of these estimates, consider a firm with leverage (12th months ago) $l$. The reaction of its credit spread to a 1-basis point positive monetary shock in the current period is $7.624 \times l$ basis points lower than that of an imaginary firm with no leverage. This does not support the initial hypothesis.

But I also analyse the dynamic reaction of spreads to monetary shocks: for a firm with 12th lag of leverage $l$, the spread will respond by ( $\Delta$ WeightedSpread $_{i t}$ ) $/\left(\Delta\right.$ leverage $_{t-12} \times$ MonetaryShock $\left._{t-k}\right) \times l$ basis points to a 1 -basis point positive monetary shock that took place $k$ periods ago. A graph of lag distribution is presented in Figure 4.

For all lags, the effect is statistically insignificant. Some of the estimated coefficients are negative, which contradicts the hypothesis, but these coefficients do not take into account the accumulated effect of monetary shock. For example, a shock at $t$ affects the spreads at $t, t+1, \ldots, t+12$ in this model. Therefore, I plot the cumulative effect (summing up the coefficients) on the next graph (Figure 5).

The graph illustrates that the cumulative effect is statistically insignificant and is negative at most lags.

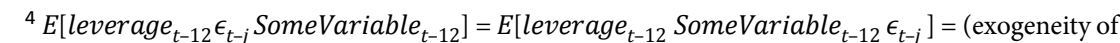
shocks $)=E\left[\right.$ leverage $_{t-12}$ SomeVariable $\left._{t-12}\right] \times E\left[\epsilon_{t-j}\right]=E\left[\right.$ leverage $_{t-12}$ SomeVariable $\left._{t-12}\right] \times 0=0$. Notice that this logic does not work when there is another interaction term: E[leverage ${ }_{t-12} \epsilon_{t-j}$ $\times$ cash $\left._{t-12} \epsilon_{t-j}\right]=E\left[\right.$ leverage $\left._{t-12} \operatorname{cash}_{t-12} \epsilon_{t-j}^{2}\right]=($ exogeneity of shocks $)=\mathrm{E}\left[\right.$ leverage $\left.{ }_{t-12} \operatorname{cash}_{t-12}\right]$ $\times E\left[\epsilon_{t-j}^{2}\right]=E\left[\right.$ leverage $\left._{t-12} \operatorname{cash}_{t-12}\right] \times \operatorname{Var}\left[\epsilon_{t-j}\right] \neq 0$. 
Figure 4. The dynamic effect of monetary shock on a weighted credit spread

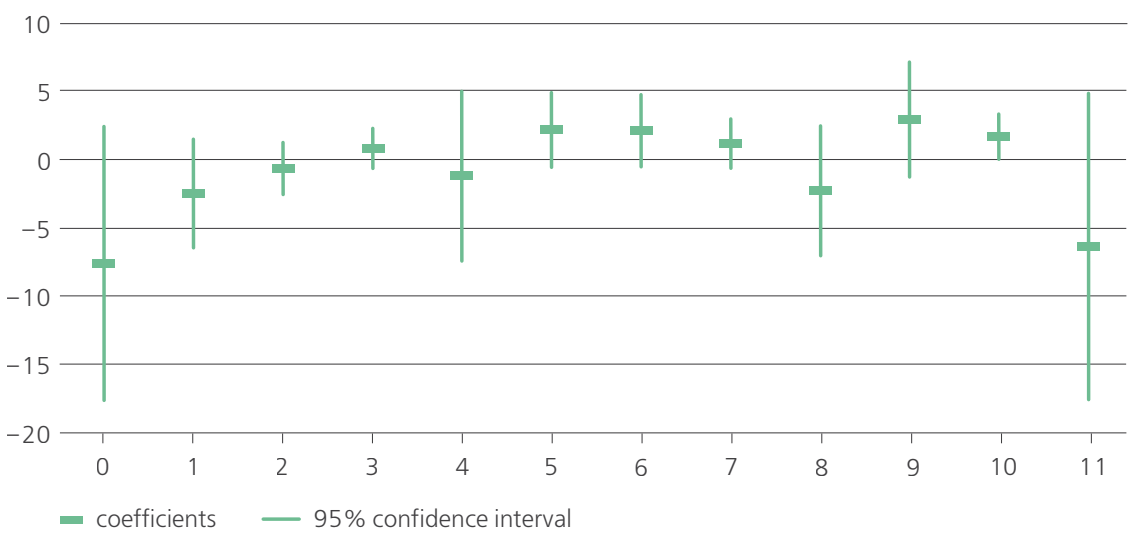

Note: This graph summarises information on the dynamic effect of a monetary shock on a firm's current weighted credit spread. From left to right, the lags go from zero to eleven.

Source: author's calculations

Figure 5. Cumulative effect of monetary shock on a weighted credit spread

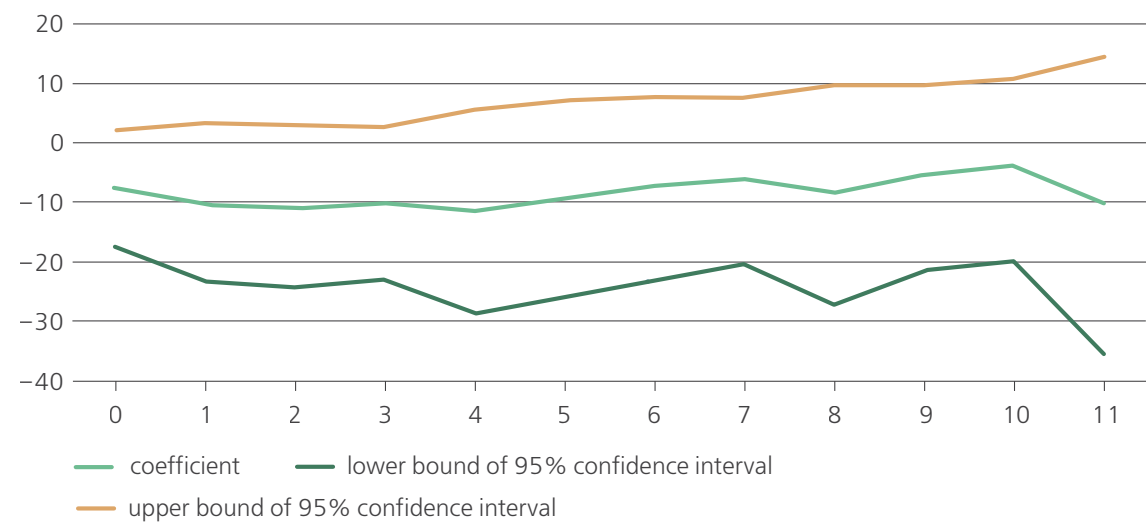

Note: This graph summarises information on the cumulative effect of monetary shock on the weighted credit spreads of a firm. From left to right, the number of lags goes from zero to eleven.

Source: author's calculations

Thus, these results do not support the theory of the balance sheet channel of monetary policy described in Section 3: the coefficients are insignificant, and some estimates are negative numbers, while they are expected to be both positive and significant. According to the theory, a positive monetary shock (corresponding to contractionary monetary policy) leads to an increase in credit spreads, and the higher is the leverage, the more pronounced is the response. These results also do not align with the findings of Anderson and Cesa-Bianchi (2020).

Estimates based on the alternative definition of leverage (total assets over net worth) are summarised in Table 8 (Appendix B). As can be seen, almost all 
coefficients are statistically significant but negative, which also contradicts the hypothesis tested. This drastic change in the significance of the estimates and their sign may be explained by the unusually high values of leverage (total assets over net worth). The firms on the right tail of the leverage distribution happened to have low credit spreads. Since the value of a leverage ratio defined in this way is not bounded above, these firms have truly large leverage: from 5,000 to 50,000. Thus, their presence in the sample may distort the estimation results considerably, because OLS estimates are sensitive to outliers. The debt over total assets ratio, therefore, seems to be a superior measure of leverage for my study.

I also check the robustness of the results to the inclusion of bonds with oferta (Table 10 in Appendix B). Bonds with oferta traded on the Russian corporate market are characterised by a combination of put and call options, which together allow researchers to treat them as series of different bonds with maturities from one oferta date to the next. Using this rule of thumb, I widen the sample (from 3,093 date-firm points to 5,403 and from 110 firms to 166 entities) and re-estimate the distributed lag model. The main conclusion does not change. No statistically significant heterogeneity is found, although the estimated coefficients are slightly different.

Ottonello and Winberry (2020) argue that the observed heterogeneity may be driven by permanent heterogeneity across firms $\left(E_{i}\left[\right.\right.$ leverage $\left.\left.{ }_{i t}\right]\right)$, so they demean leverage in their empirical test in order to avoid omitted variable bias. If permanent heterogeneity affects credit spreads in the same direction as indebtedness at period $t$, then the bias is positive, meaning that the coefficients of interest are overestimated. I repeat the estimation with demeaned values of leverage, but neither the precision of the estimates (standard errors) nor the coefficients themselves change significantly (Table 9 in Appendix B).

\subsection{Local projection model}

Next, I estimate a local projection model. This specification is similar to that of Anderson and Cesa-Bianchi (2020), except that they estimate theirs on quarterly data.

$$
\begin{aligned}
& \text { WeightedSpread }_{i, t+h}=\beta_{0}+\gamma_{i}^{h}+\alpha_{t}^{h} \\
& +\beta_{1}^{h} \text { leverage }_{i t-1} \text { MonetaryShock }_{t}+\text { controls }+\epsilon_{i, t+h},
\end{aligned}
$$

where $\gamma_{i}^{h}$ and $\alpha_{t}^{h}$ are firm- and time-fixed effects.

In contrast to the distributed lag model, here, the coefficients before each lag are estimated separately, and, thus, fewer observations are dropped for smaller lags compared with the first model, where all coefficients must be estimated on the same sample.

The estimation results are presented in Figure 6. 
Figure 6. Estimates of the coefficients $\beta$ by the method of local projections

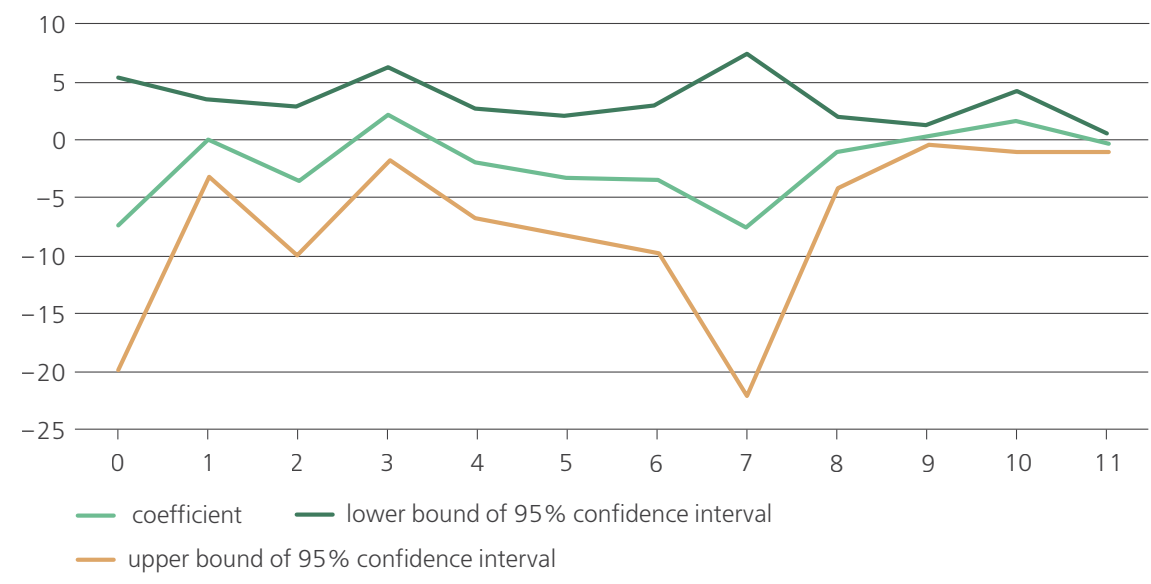

Note: From left to right, the lags go from zero to eleven.

Source: author's calculations

As is seen, all the coefficients are insignificant. The estimates themselves vary a little compared with Table 5 , but this is not surprising, given that they are estimated on slightly larger samples. Despite this fact, the estimates at more distant lags, which are estimated on approximately the same sample as the distributed lag model, are quite similar to those obtained in Section 5.1, which may indirectly confirm the fundamental assumption of the rationality of consensus policy rate forecasts and, in particular, of the independence of monetary shocks over time: if $E\left[\epsilon_{t-j} \epsilon_{t-k}\right]=0$, then $E$ [leverage ${ }_{t-12} \epsilon_{t-j} \times$ leverage $\left._{t-12} \epsilon_{t-k}\right]=E_{\text {leverage }}^{2}$ $\left.\times \epsilon_{t-j} \epsilon_{t-k}\right]=(\epsilon$ is exogenous $)=E\left[\right.$ leverage $\left._{t-12}^{2}\right] \times E\left[\epsilon_{t-j} \epsilon_{t-k}\right]=E\left[\right.$ leverage $\left._{t-12}^{2}\right]$ $\times 0=0$, so the coefficients should not change a lot when more lags are included in the distributed lag model.

The local projection estimates contradict the initial hypothesis: the coefficients are statistically insignificant and some of them are negative, which implies that more levered firms are less responsive to monetary shocks. These results do not align with those found by Anderson and Cesa-Bianchi (2020), ${ }^{5}$ but they do agree with the estimates of the distributed lag model (Model 1).

\section{Discussion}

\subsection{Theoretical explanation of the results}

In the more general setting when the amount of investment is endogenous, a credit spread's reaction to a change in the interest rate is not especially obvious.

5 They find statistically significant positive estimates at a short horizon. 
Anderson and Cesa-Bianchi $(2018,2020)$ demonstrate that when we take into account both capital supply

$$
\frac{E\left\{R_{t+1}^{k}\right\}}{R_{t}}=f\left(\frac{Q_{t} K_{t+1}^{j}}{N_{t}}\right),
$$

where $Q K=N+B$, and capital demand

$$
\frac{E\left\{R_{t+1}^{k}\right\}}{R_{t}}=\frac{1}{R}\left(\alpha K_{t}^{\alpha-1}+\frac{Q^{\prime}(1-\delta)}{Q}\right),
$$

the interest rate affects both of them, and the total effect depends on which of these two effects dominates.

Anderson and Cesa-Bianchi (2018, p. 19, Figure 'Monetary policy tightening: The credit channel') demonstrate the effect of a change in the key rate $R_{t}$ on the equilibrium external finance premium and amount borrowed ( $Q K$ in the terminology of Bernanke et al., 1999): demand for capital goes down, both with an increase in $R$ and a fall in asset prices $Q^{\prime}$. At the same time, the supply of capital decreases due to the fall in net worth, which occurs as a result of the depreciation of assets (and $f()$ is an increasing function). If the first effect dominates, the new equilibrium is at point $C 1$, which is characterised by a lower external finance premium compared to the initial point $A$. However, if the supply reacts more than demand, then the new equilibrium is at point $C 2$ and the external finance premium grows. Moreover, more levered firms (in the terms they use, these are firms with higher $B / N$ ratios) are more responsive to interest rate shocks in this case, because its initial equilibrium point lies at a steeper part of the curve (see Anderson and Cesa-Bianchi, 2018, p. 15, Figure 'Credit (Capital) market equilibrium: Heterogeneity'). The second situation is likely to take place in the US debt market, which is not surprising given that the US economy is saturated with capital and has a low marginal product of capital, which determines demand for it. As an emerging economy, Russia is characterised by a large marginal product of capital, and so its capital demand should be very responsive to monetary shocks. This may explain why the estimates in the previous section are statistically insignificant.

\subsection{Concerns about data and methodology}

As I mentioned in the Section 4.2, the fact that some firms defaulted on their bonds before they matured (did not manage to pay their coupons) may bias the estimates towards weaker effects: these firms are likely to be more responsive to monetary shocks. Only those bonds that have been floating in the market for at least twelve months and have experienced at least twelve monetary shocks are included in the final sample. However, these defaulted bonds may have been on the 
market for a shorter period. Once they are removed from the sample, it is less likely that a statistically significant effect can be found among the remaining companies. To address this concern, I analysed the frequency of defaults. Only 14 companies were excluded from the final sample due to defaults on their coupons. This is an insignificant number which is unlikely to cause bias given that the total size of the sample is 110 . Moreover, when I estimate the local projections model, these companies are included in the samples that are used to estimate the coefficients at less distant lags (for example, one period ahead), and the results of the estimation do not change much (Figure 6). This could be suggestive evidence against the concern of selection bias caused by technical defaults before maturity.

Once the initial hypothesis of the heterogeneity of the reaction of firms' credit spreads to monetary shocks is rejected, it is natural to analyse which part of the mechanism described in Section 3 does not work. It is difficult to test whether there is a negative relation between the external finance premium and the net worth of a firm (which is suggested by the costly state verification model from Bernanke et al. (1999) and the simpler version of it with specific functions proposed by Romer (2011)). Indeed, net worth is clearly an endogenous variable, and it is hard to come up with an instrument for it. However, we can test the idea from Boivin et al. (2010) that the net worth of a more levered firm reacts to a positive monetary shock (an unexpected increase in the policy rate) with a larger decrease. To test this mechanism, I estimate the following model on quarterly data:

$$
\begin{aligned}
& \text { NetWort } h_{i, t+h}=\beta_{0}+\alpha_{i}^{h}+\beta_{1}^{h} \text { MonetaryShock } k_{t}^{h} \\
& +\beta_{2}^{h} \text { leverage } \text { lev-1 }_{\text {MonetaryShock }}+\text { controls }+\epsilon_{i, t+h},
\end{aligned}
$$

where $\alpha_{i}^{h}$ is firm-fixed effects and $h$ changes from zero to three.

The set of controls consists of the previous (at $t-1$ ) values of size, leverage, and cash of firm $i$. Since the data are quarterly, $t$ denotes a quarter. The results of the estimation are presented in Table 12 (Appendix C). As is visible, the effect of monetary shocks on the net worth of a firm is statistically insignificant even though it has the expected sign: an increase in the policy rate leads to a decrease in the net worth of a firm. However, the sign of the estimate of the interaction term does not go in line with the initial hypothesis: more levered firms are less sensitive to unexpected changes in the policy rate.

The failure to find a significant effect here (and in the previous models) may be explained by the quality of the data being used. First, I used book values that are self-reported by the firms. These may be less sensitive to monetary shocks even though many components of the balance sheet are marked to market. Nevertheless, book values are often used in microlevel analysis of firms' financials. For example, Anderson and Cesa-Bianchi (2020) also use book values. Second, some firms may have no debt obligations with floating rates of return, but the model of the balance sheet channel relies on the implicit assumption that the rate 
on a firm's debt is floating. More granular data including the fraction of debt with floating interest rate payments could, therefore, be very useful. A study of a group of firms with a high amount of interest payments with floating rates (which are sensitive to monetary policy) would offer a better chance to see the balance sheet channel working.

\section{Conclusion}

For the Bank of Russia, as well as for other regulators, it is important to understand the mechanisms of monetary policy transmission. The theory of demand-side financial imperfections - represented by the well-known costly state verification model of Bernanke et al. (1999) laid out in Section 3 - lays the foreground for the balance sheet channel analysis.

To the best of my knowledge, this is one of the first studies devoted to financial imperfections and the balance sheet channel of monetary policy in Russia or in a developing economy in general that uses granular credit spread data. Another paper that uses credit spreads to approximate the unobserved external finance premium and studies the heterogeneity of its responses to monetary shocks is that of Anderson and Cesa-Bianchi (2020). They report heterogeneity in the reactions of the US firms to monetary policy shocks that agrees with the theoretical models outlined in first sections of this paper. Given that the US corporate bond market is quite liquid, the authors apply an event-study approach to estimate their model.

I estimate two models: a distributed lag model and a local projection model. Compared to event-study approach applied by Anderson and Cesa-Bianchi (2020), both models seem to be more suitable in the context of Russia, because the local corporate bond market is not as liquid as that of the US and the price response to monetary shocks may, therefore, be significantly delayed.

The results of estimation and multiple robustness checks suggest that in the Russian market, the external finance premium of low-levered firms and more indebted companies react to monetary policy shocks in the same way. This means that the decision-making process of the Bank of Russia as concerns the availability of external finance for Russian firms could be a little easier.

This finding does not support the initial hypothesis based on the theory and the results reported by Anderson and Cesa-Bianchi (2020). One possible interpretation is that the impact of financial imperfections in the Russian market is not particularly pronounced because the response of the credit supply schedule is offset by a pronounced reaction of the credit demand (due to the large marginal product of capital). Also, it could be the case that the identification assumption of the exogeneity of monetary shocks, defined as the difference between actual rates and consensus policy rate forecasts, does not hold. However, suggestive evidence in favour of the rationality of the forecasts (no serial correlation and zero mean error) and the results of the robustness checks (inclusion of additional controls) enhance 
the trust in this measure of monetary shock. Other concerns about the data used are addressed in the previous section.

An area for future research could be the finding of better data and preprocessing methods and applying them to other emerging market economies. With a relatively low level of capital stock, they are characterised by a large marginal product of capital, which renders the demand for it susceptible to changes in the interest rate. Thus, this idea could be supported or rejected via additional research of emerging market economies similar to the analysis done here. Additionally, empirical papers on the balance sheet channel are relatively scarce, especially papers devoted to the external finance premium directly and not to the amounts borrowed, and, therefore, the marginal contribution of each new study devoted to this topic could be significant.

Appendices are available at http://rjmf.econs.online/en; doi.org/10.31477/rjmf.202104.03

\section{References}

Anderson, G. and Cesa-Bianchi, A. (2018). Firm Heterogeneity, Credit Spreads, and Monetary Policy. Paper Presented at ECB Workshop: Monetary Policy and Financial Stability, 17-18 December. https://www.ecb.europa.eu/pub/conferences/shared/ pdf/20181217_monpol/CesaBianchi_FirmHeterogeneity.pdf [accessed on 28 October 2021].

Anderson, G. and Cesa-Bianchi, A. (2020). Crossing the Credit Channel: Credit Spreads and Firm Heterogeneity. IMF Working Paper, N 267.

Bernanke, B., Gertler, M. and Gilchrist, S. (1999). The Financial Accelerator in a Quantitative Business Cycle Framework. In: J. B. Taylor and M. Woodford, eds. Handbook of Macroeconomics, Vol. 1. Elsevier, pp. 1341-1393.

Boivin, J., Kiley, M. T. and Mishkin, F. (2010). How Has the Monetary Transmission Mechanism Evolved Over Time? In: B. M. Friedman and M. Woodford, eds. Handbook of Monetary Economics, Vol. 3. Elsevier, pp. 369-422.

Borzykh, O. (2016). Bank Lending Channel in Russia: A TVP-FAVAR Approach. Applied Econometrics, 43, pp. 96-117. [In Russian].

Brissimis, S. N., Papafilis, M. and Vlassopoulos, T. (2018). Some Thoughts on the External Finance Premium and the Cost of Internal Finance. Munich Personal RePEc Archive (MPRA) Paper, N 85261.

Caldara, D. and Herbst, E. (2019). Monetary Policy, Real Activity, and Credit Spreads: Evidence from Bayesian Proxy SVARs. American Economic Journal: Macroeconomics, 11(1), pp. 157-92. https://www.doi.org/10.1257/mac.20170294

Claessens, S. and Kose, M. A. (2018). Frontiers of Macrofinancial Linkages. BIS Papers, N 95. 
Cloyne, J., Ferreira, C., Froemel, M. and Surico, P. (2018). Monetary Policy, Corporate Finance and Investment. NBER Working Paper, N 25366.

De Graeve, F. (2008). The External Finance Premium and the Macroeconomy: US PostWWII Evidence. Journal of Economic Dynamics Control, 32(11), pp. 3415-3440. https://doi.org/10.1016/j.jedc.2008.02.008

Du, W., Tepper, A. and Verdelhan, A. (2018). Deviations from Covered Interest Rate Parity. Journal of Finance, 73(3). pp. 915-957. https://doi.org/10.1111/jofi.12620

Gertler, M. and Karadi, P. (2015). Monetary Policy Surprises, Credit Costs, and Economic Activity. American Economic Journal: Macroeconomics, 7(1), pp. 44-76. https://www.doi.org/10.1257/mac.20130329

Gilchrist, S. and Zakrajšek, E. (2012). Credit Spreads and Business Cycle Fluctuations. American Economic Review, 102(4), pp. 1692-1720. https://doi.org/10.1257/aer.102.4.1692

Jeenas, P. (2019). Monetary Policy Shocks, Financial Structure, and Firm Activity: A Panel Approach. CREI Working Paper. https://crei.cat/wp-content/uploads/2020/06/Jeenas_ MPSLA_20190702.pdf [accessed on 28 October 2021].

Ottonello, P. and Winberry, T. (2020). Financial Heterogeneity and the Investment Channel of Monetary Policy. Econometrica, 88(6), pp. 2473-2502. https://doi.org/10.3982/ECTA15949

Primiceri, G. E. (2005). Time Varying Structural Vector Autoregressions and Monetary Policy. Review of Economic Studies, 72(3), pp. 821-852. https://doi.org/10.1111/j.1467-937X.2005.00353.x

Romer, D. (2011). Advanced Macroeconomics, 4th ed. McGraw-Hill.

Tishin, A. (2019). Monetary Policy Surprises in Russia. Russian Journal of Money and Finance, 78(4), pp. 48-70. https://doi.org/10.31477/rjmf.201904.48 